\title{
Prevention of cardiovascular disease in a rural general practice
}

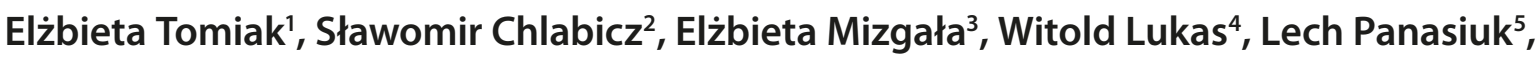 \\ Witold Drzastwa ${ }^{3}$, Agnieszka Jankowska-Zduńczyk ${ }^{6}$ \\ ${ }^{1}$ VITA Team Doctor Family, Training Centre of Family Physicians in Otyniu, Poland \\ ${ }^{2}$ Department of Family Medicine and Community Nursing, Medical University of Bialystok, Poland \\ ${ }^{3}$ Department of Family Medicine in Zabrze, Medical University of Silesia in Katowice, Poland \\ ${ }^{4}$ Department of Public Health, Faculty of Management, University of Czestochowa, Poland \\ ${ }^{5}$ Department of Internal Medicine, Hypertension and Occupational Diseases Rural Medicine Institute in Lublin, Poland \\ ${ }^{6}$ Specialist Medical Practice in Warsaw, Poland
}

Tomiak E, Chlabicz S, Mizgała E, Lukas W, Panasiuk L, Drzastwa W, Jankowska-Zduńczyk A. Prevention of cardiovascular disease in a rural general practice. Ann Agric Environ Med. 2016; 23(4): 553-558. doi: 10.5604/12321966.1226845

\section{Abstract}

Introduction. Cardiovascular disease (CVD) prophylaxis in general practice, especially in rural areas, is a major organizational challenge.

Objective. The aim of this study was to determine the prevalence of CVD risk factors in the studied population, and to identify the effect of the number of planned prophylactic consultations on selected clinical parameters, risk factors, and total cardiovascular risk on the SCORE scale (Systemic Coronary Risk Evaluation).

Materials and method. The study included patients of a rural general practice, aged 35-55 years, with at least one modifiable CVD risk factor. Medical history was obtained, a physical examination performed, blood glucose levels, lipid profile, BMI, waist circumference and blood pressure measured and the SCORE cardiovascular risk at baseline and at the end of the study calculated. All participants were provided with targeted specific education. Analysis was performed in two groups of patients (1 and 2), where group 1 had one more prophylactic consultation than Group 2.

Results. The results at baseline and a year later were compared in pharmacologically untreated patients, 26 in Group 1 and 34 in Group 2. In Group 1, which had had more prophylactic consultations, a statistically significant decrease was found in the mean systolic blood pressure: $131.000-124.782(p=0.02721)$, mean diastolic blood pressure: $86.846-83.462(p=0.01111)$, and a statistically significant decrease in total cardiovascular risk on the SCORE scale $(p=0.0478)$.

Conclusions. The higher number of preventive consultations had an impact on a statistically significant decrease in mean blood pressure and mean SCORE value. The year-long cardiovascular disease prophylaxis programme proved less effective than expected, and neither a decrease in body weight nor an improvement in lipid metabolism was achieved in any of the groups.

\section{Key words}

cardiovascular risk factors, prevention, primary care

\section{INTRODUCTION}

The present day lifestyle promotes the development of cardiovascular diseases (CVDs), which account for nearly $50 \%$ of deaths - $48 \%$ in Europe and $42 \%$ in the European Union. This is the greatest health issue affecting Europeans. CVDs are also the main cause of death in Poland, as shown by the NATPOL 2011 Survey published in Warsaw on 14 September 2011 [1].

Statistical data regarding the prevalence of cardiovascular risk factors in adults are unfavourable. According to the NATPOL 2011 study, 32\% of adult Poles (18-79 years) have hypertension, $61 \%$ are affected by dyslipidaemia, $27 \%$ are smokers, $5 \%$ have diabetes, and $22 \%$ are obese [1]. In Poland, analyses using the SCORE algorithm have shown that lipid disorders are a major risk factor for coronary incidents. Hypertension is in second place and smoking third [2]. The increased cardiovascular risk associated with hypertension

Address for correspondence: Elżbieta Tomiak, VITA Team Doctor Family, Training Centre of Family Physicians in Otyń, Dworcowa 2, 67-106 Otyń, Poland

E-mail: pvita@o2.pl

Received: 05 March 2015; accepted: 15 December 2015 already begins at $115 \mathrm{mmHg}$ systolic blood pressure and $75 \mathrm{mmHg}$ diastolic blood pressure [3,4]. Even a slight decrease, by $2 \mathrm{mmHg}$, in mean blood pressure has clinical significance and affects risk. Lowering blood pressure to $120 / 80$ reduces the number of myocardial infarctions, strokes, heart defects, and kidney diseases, as well as prolonging life [4]. Overweight and obesity are also important risk factors. There is an epidemic of obesity, both in adults and children. It is estimated that more than 1 billion people worldwide are overweight and over 300 million are obese $[3,5]$.

About $50 \%$ of deaths (the effects of treatment are estimated at $40 \%$ ) can be prevented by eliminating or modifying the risk factors.

Cardiovascular risk assessment scales which take into account risk factors are a very useful tool in clinical practice. The SCORE [6] scale (Systemic Coronary Risk Evaluation) is the only example of such a tool calibrated for Poland. The SCORE scale allows determination of the overall risk of death from cardiovascular causes over the next 10 years of a patient's life. Primary, easily measurable risk factors, such as gender, age, smoking status, systolic blood pressure and total cholesterol levels or total cholesterol/HDL cholesterol quotient, are included in the risk calculation 
using the SCORE scale. The calculated risk is expressed as a percentage and classified to one of four categories: low $(<1 \%)$, moderate $(1-4 \%)$, increased (5-9\%), and significantly increased $(\geq 10 \%)[6]$

A significant number of consultations in general practice concern cardiovascular diseases. In the case of chronic CVDs, general practitioners have noted hypertension as a growing health concern. The NATPOL 2011 Survey showed the need to reinforce prevention and education throughout the population, starting from an early age, in order to reduce the risk factors for cardiovascular diseases. This encourages practitioners to take preventive measures in this regard, based on the principle that it is better to prevent than to treat. A variety of cardiovascular disease prevention programmes, including the one founded by the National Health Service which was the starting point for this study, as well as other programmes in local level have been implemented in primary care practices. CVD prophylaxis in a small general practice, especially in rural areas, is a major organizational challenge for a physician and requires proven measures to be undertaken. Repeating prophylactic recommendations and the use of patient-centred motivational techniques are factors significantly affecting the effectiveness of CVD prevention. The presented study is an attempt to illustrate the above-mentioned issue based on the example of a small rural general practice.

\section{OBJECTIVE}

The aim of this study was to determine the prevalence of CVD risk factors in a studied population aged $35-55$ years, and to identify the effect of the number of planned prophylactic consultations on CVD risk factors, and total cardiovascular risk according to the SCORE scale. The age group was the same as the target group eligible to participate in the national screening program for cardiovascular risk factors currently implemented by National Health Fund in Poland. We assumed that a series of prophylactic consultations combined with health education may result in positive health behaviors, improved clinical parameters and, consequently, a reduction in modifiable CVD risk factors in patients in the care of a general practitioner.

\section{MATERIAL AND METHODS}

The study included patients aged 35-55 years with at least one modifiable CVD risk factor and/or a positive family history of cardiovascular diseases (CVDs). under the care of a primary health care clinic in the rural area of Otyn, Nowosolski County, in the Lubusz Province of western Poland.

The health care practice in Otyn has 3,971 patients. The provided health services are typical of primary health care and general practitioner competencies and their scope is very wide - from vaccinations and routine health checks for children to minor surgeries.

The subjects involved in the study were selected from patients attending the general practice for a variety of reasons and who fulfilled the criteria, and agreed to participate in the study. The patients were randomly assigned to group 1 or 2 (on a first-come first served basis). The exclusion criteria were as follows: established heart disease, chronic kidney disease, liver insufficiency, disabilities affecting mobility, and lack of consent,. People with dyslipidaemia, hypertension or diabetes mellitus were elegible to participate provided they did not receive any medications for those conditions.

Patients who presented at the clinic were provided with prophylactic consultations by a general practitioner's team (a physician and a community nurse) in a predetermined way, with a certain frequency and within a given time (summarizing assessment after a year, partial assessment after each visit). Two physicians (specialists in family medicine) and two community nurses involved in the study performed the medical tests and provided consultations in accordance with s determined scheme (Tab. 1).

Table 1. Intervention scheme

Group 1

1) Qualifying consultation + survey 1

2) After 1 month - maintenance consultation with an Individual Action Plan for the patient + survey 2

3) Check-up consultation - took place within 3-6 months after the maintenance consultation (consultation with a nurse and interview verifying health habits, as well as consultation with a physician) + survey 3

4) After 1 year - final summarizing consultation + survey 4

Group 2

1) Qualifying consultation + survey 1

1) After 1 month - maintenance consultation with an Individual Action Plan for the patient + survey 2

2) After 1 year - final summarizing consultation + survey 4

Group 1 received 1 more prophylactic consultation than Group 2

Total cardiovascular risk was calculated for each patient using the SCORE scale. Computer visualizations (Figs. 1, 2) and Individual Action Plans (Annex 1) were used to motivate lifestyle changes. Fasting blood glucose levels, lipid profile, BMI; waist circumference, blood pressure, and heart rate were assessed. Blood pressure measurements were performed according to methodology described in the NATPOL PLUS study. Measurements were taken after 15 minutes of rest, in a sitting position, with arm positioned at the heart level. An automatic blood pressure measuring machine of the Omron type was used, with arm bands in three sizes depending on arm circumference (according to WHO/ISH recommendations). Measurements were taken three times at two minute intervals. The first measurement was discarded; only the mean was calculated from the second and third for systolic and diastolic blood pressure measurements. These measurements were performed at baseline and a year later at the end of the study. The study was documented using the appropriate medical charts and original surveys.

The arithmetic mean, standard deviation values for measurable characteristics was calculated in both groups. T-student test was applied to compare mean values of clinical parameters in the two groups. To evaluate changes of blood pressure over time in each of the groups, the Friedman ANOVA test was used. Wilcoxon matched pairs test was applied to compare SCORE risk values at first and final consultations. A level of $\mathrm{p}<0.05$ was considered statistically significant.

The study was approved by the Bioethics Committee of the Medical Chamber in Zielona Góra (No. 4/36/2007).

The study was carried out with the agreement number KNW-1-208/N/5/0 


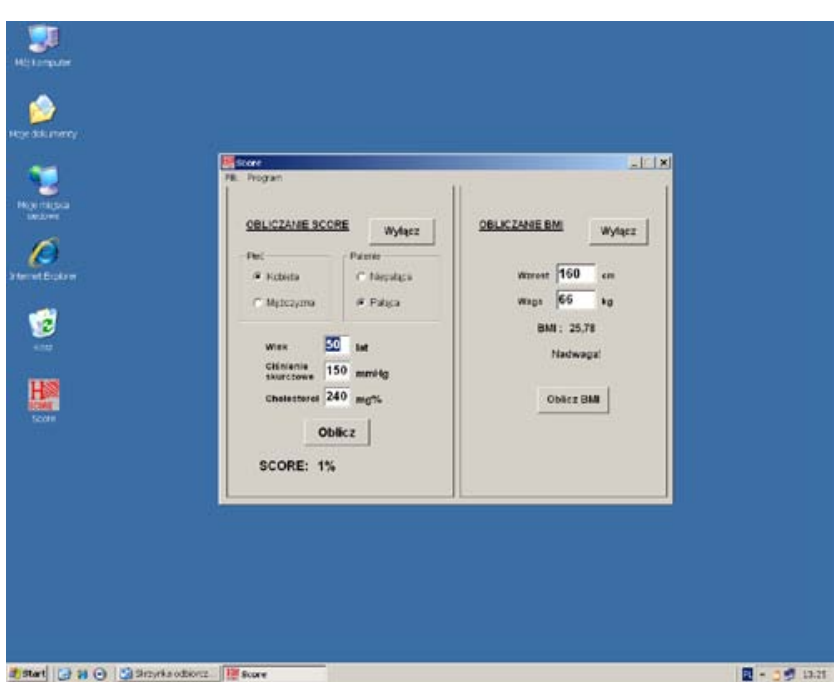

Figure 1. Software for calculating SCORE and BMI

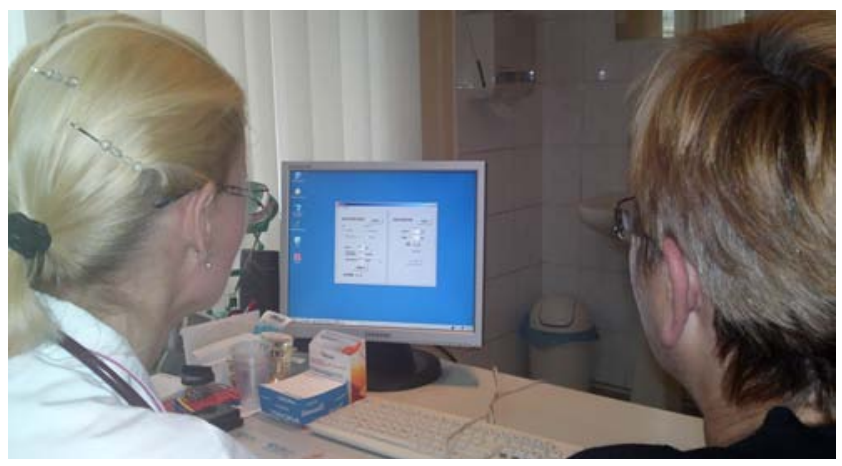

Figure 2. Visualization of changes in SCORE and BMI in the presence of the patient

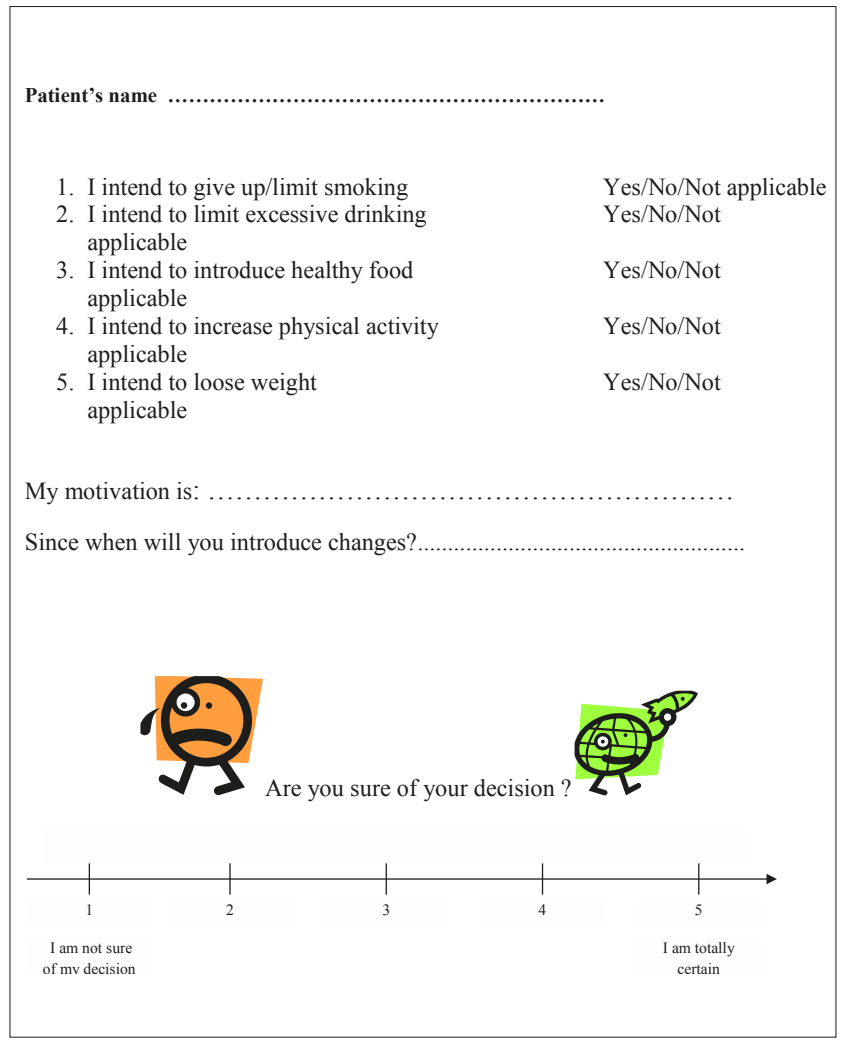

Annex 1. Individual Action Plan

\section{RESULTS}

A total of 124 patients had a qualifying prophylactic consultation. The study was completed by 90 patients $(42$ patients from Group 1 and 48 patients from Group 2) after the fourth (summarizing) consultation, which is $72.6 \%$ of the 124 patients who had had the first qualifying consultation. In both groups, a comparative analysis with respect to the value of the total SCORE-based risk, blood pressure, lipid and glucose levels was performed (values from consultation one versus consultation four), and only the results for pharmacologically untreated patients - 26 in Group 1 and 34 in Group 2 - were taken into account. There was a similarity between the two groups in terms of gender and age. No statistically significant differences were found between the two groups. Females predominated in both groups (59.52\% in Group 1; 64.58\% in Group 2). Mean age in both groups was 48 years. Nor were any differences found between the groups in terms of education. Patients with primary and vocational education predominated (more than 60\%). No statistically significant differences were found in baseline values of the assessed parameters (Tab. 2).

Prevalence of risk factors and the impact of prophylactic consultations on these factors. Abnormal body weight (overweight and obesity) was calculated in $67.8 \%$ of the patients (Groups 1 and 2). Obesity was found in $30.0 \%$ of the patients, and $37.8 \%$ were overweight. Abnormal (based on standard ranges) levels of total and LDL cholesterol occurred in $67.8 \%$; abnormal levels of HDL cholesterol in $7.8 \%$, triglycerides in $23.3 \%$, and glucose in $11 \% .54 .4 \%$ of patients were found to have increased blood pressure at baseline. Family history of cardiovascular diseases in the two groups was as follows:
Recommendations concerning physical activity

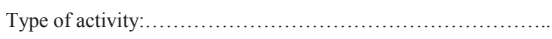

Number of minutes daily: $\square 10 \square 15 \square 20 \square 25 \square 30 \square$ more than 30 minutes

How many times a week: $\square 3 \mathrm{x} \square 4 \mathrm{x} \square 5 \mathrm{x} \square 6 \mathrm{x} \square$ every day

Level of intensity:

$\neg$ Low (30-50\% max pulse)

$\neg$ Moderate $(50-70 \%$ max pulse)

$\neg$ High (70-905 max pulse)

Recommendations concerning diet:

Number of calories: $\square 1000 \mathrm{kcal} \square 1200 \mathrm{kcal} \square 1400 \mathrm{kcal} \square 1600 \mathrm{kcal}$ isocaloric diet

low fat diet

low salt diet

low simple carbohydrates diet 
Table 2. Comparison of mean values of clinical parameters in Groups 1 and 2 at the beginning of the study

\begin{tabular}{lccc}
\hline Parameter (mean values) & $\begin{array}{c}\text { Group 1 } \\
\text { Consultation 1 } \\
\mathrm{n}=26\end{array}$ & $\begin{array}{c}\text { Group 2 } \\
\text { Consultation 1 } \\
\mathrm{n}=34\end{array}$ & $\begin{array}{c}\mathrm{t} \text {-Student } \\
\text { test }\end{array}$ \\
\hline BMI & 28.429 & 27.553 & $\mathrm{p}=0.592$ \\
\hline Waist circumference $(\mathrm{cm})$ & 95.250 & 93.250 & $\mathrm{p}=0.4601$ \\
\hline Systolic blood pressure $(\mathrm{mmHg})$ & 131.00 & 125.676 & $\mathrm{p}=0.3330$ \\
\hline Diastolic blood pressure $(\mathrm{mmHg})$ & 86.846 & 87.402 & $\mathrm{p}=0.4433$ \\
\hline Total cholesterol $(\mathrm{mg} / \mathrm{dl})$ & 206.962 & 194.191 & $\mathrm{p}=0.2700$ \\
\hline HDL cholesterol $(\mathrm{mg} / \mathrm{dl})$ & 62.192 & 63.76 & $\mathrm{p}=0.2423$ \\
\hline LDL cholesterol $(\mathrm{mg} / \mathrm{dl})$ & 132.654 & 118.565 & $\mathrm{p}=0.1381$ \\
\hline Triglycerides $(\mathrm{mg} / \mathrm{dl})$ & 126.385 & 106.450 & $\mathrm{p}=0.2597$ \\
\hline Glucose $(\mathrm{mg} / \mathrm{dl})$ & 87.654 & 81.929 & $\mathrm{p}=0.1090$ \\
\hline SCORE & $\mathbf{0 . 9 2 3}$ & $\mathbf{0 . 7 6 5}$ & \\
\hline
\end{tabular}

- many patients - $19.05 \%$ in Group 1 and $18.75 \%$ in Group 2 - reported myocardial infarction in the father before the age of $55 ; \mathrm{m}$

- yocardial infarction in the mother before the age of 60 was reported by $7.5 \%$ of patients in Group 1, but by none in Group 2;

- stroke in the father before the age of 55 was reported by $0 \%$ in Group 1 and $4.17 \%$ in Group 2;

- stroke in the mother before the age of 60 was reported by about $2 \%$ of patients in both groups.

At baseline, $28.57 \%$ of patients in Group 1 and $36.17 \%$ in Group 2 reported smoking, 77.50\% in Group 1 and 82.98\% in Group 2 reported alcohol consumption, and 30.95\% in Group 1, and $45.83 \%$ in Group 2 reported insufficient physical activity. As a result of prophylactic consultations, the number of patients from both groups reporting smoking and alcohol consumption reduced, and the number of physically active patients increased. In Group 1, 11.91\% stopped smoking and $7.14 \%$ reduced smoking. The number of patients consuming alcohol decreased by $34.64 \%$. At the fourth consultation, $14.28 \%$ of patients declared increased physical activity. In Group 2, $15.65 \%$ stopped smoking and 2.08\% reduced smoking. The number of patients consuming alcohol decreased by $51.4 \%$. At the fourth consultation, $31.28 \%$ declared increased physical activity.

Effects of prophylactic consultations on clinical parameters and SCORE. No statistically significant differences were found in the baseline values of the studied parameters in patients not treated pharmacologically (Tab. 2). In terms of clinical parameters, the following differences between the results obtained during consultations 1 and 4 were found one year after the start of the study:

- a statistically significant decrease in mean systolic and diastolic blood pressure, as well as in total cardiovascular risk in the SCORE algorithm was found in Group 1, which had had more prophylactic consultations;

- mean systolic blood pressure decreased in Group 1, from 131.000-124.782 (-6.218; $\mathrm{p}=0.02721)$; mean diastolic blood pressure decreased from 86.846 to $83.462(-3.384$; $\mathrm{p}=0.01111)($ Tab. 3, 4);

- in Group 1, mean systolic blood pressure decreased by nearly $5 \%$ and mean diastolic blood pressure by $4 \%$, compared with baseline values;
- group 1 also had a statistically significant decrease in total CVD risk according to the SCORE scale $(\mathrm{p}=0.0478)$ at the end of the study;

- mean SCORE value in Group 1 was 0.923\% (95\% confidence interval $0.278-1.569)$ at baseline, and decreased at consultation four to $0.654 \%(-0.26 ; 95 \%$ confidence interval from 0.212-1.095).

Table 3. Analysis of the dynamics of change in systolic blood pressure values in Group 1

\begin{tabular}{lcc}
\hline $\begin{array}{l}\text { Systolic blood pressure (SBP) } \\
\mathrm{N}=26\end{array}$ & Mean & Standard deviation \\
Consultation (C) & & \\
\hline SBP -C1 & 131.000 & 15.246 \\
\hline SBP -C2 & 128.551 & 13.990 \\
\hline SBP -C3 & 130.872 & 12.055 \\
\hline SBP -C4 & 124.782 & 12.162
\end{tabular}

$\mathrm{p}=0.02721 ; \mathrm{SBP}-$ systolic blood pressure; C1, C2, C3, C4 - consultation 1,2,3,4

Table 4. Analysis of diastolic blood pressure values in Group 1

\begin{tabular}{llc}
\hline Diastolic blood pressure (DBP) & Mean & Standard deviation \\
$\begin{array}{l}\mathrm{N}=26 \\
\text { Consultation (C) }\end{array}$ & 86.846 & \\
\hline DBP-C1 & 82.462 & 8.823 \\
\hline DBP-C2 & 86.256 & 9.076 \\
\hline DBP-C3 & 83.462 & 7.015 \\
\hline DBP-C4 & & 7.040 \\
\hline
\end{tabular}

$\mathrm{p}=0.01111$; DBP- diastolic blood pressure; C1, C2, C3, C4 - consultation 1,2,3,4

There were no such changes in Group 2; no statistically significant decrease was found in mean systolic blood pressure. In contrast to Group 1, Group 2 had a statistically significant increase in parameters such as BMI, waist circumference, and triglyceride levels. A statistically insignificant increase in mean SCORE value $(\mathrm{p}=0.7988)$ was also observed in Group 2. Mean SCORE value was $0.765 \%$ (95\% confidence interval $0.410-1.119)$ at consultation one, and increased to $1.147 \%$ (+0.382; 95\% confidence interval $0.221-2.07)$ at consultation four.

Neither a decrease in body weight nor an improvement in lipid metabolism was achieved in either of the groups.

\section{DISCUSSION}

The starting point of the presented study was a National Health Service cardiovascular disease prophylaxis programme implemented in a small rural medical practice.

Prevention at the population level through lifestyle and environment changes proved to be the most effective way to control the epidemic of cardiovascular diseases (CVDs) and improve public health, as highlighted in the summary of results for the North Karelia Project in 2010 [7]. The majority of the interviewed patients (about 19\%) reported myocardial infarction in the father before the age of 55. As in other studies [8], early onset myocardial infarctions in females (mothers) were significantly less frequent compared with males (fathers). In the presented study, the prevalence of CVD risk factors was comparable to the prevalence in other studies in Poland - NATPOL PLUS, WOBASZ, 400 Cities Project, POLSCREEN, LIPIDGRAM $[9,10,11,12]$, and the 
differences, if any, resulted among others from the different age ranges of the participants.

In addition to determining the prevalence of CVD risk factors in the study population, an assessment of the effects of the number of prophylactic consultations on selected risk factors and clinical parameters was performed, and thus a comparative assessment of the efficacy of preventive measures in Groups 1 and 2 with varying numbers of consultations. It was assumed that reminders (repeating prophylactic information during subsequent visits) play an important role in encouraging a patient to adhere to prophylactic recommendations. In both Groups 1 and 2 there was a decrease in the number of smokers and alcohol consumers, as well as an increase in those engaging in physical activity. The changes were statistically significant for all the above risk factors in Group 2, whereas only one statistically significant difference with respect to a decrease in alcohol consumption was observed in Group 1. Such unexpected results may because of the fact that the awareness and motivation of the patients participating in the year-long study may have been positively or negatively affected by a variety of external factors, such as mass media, psychological or family. The impact and distribution of these factors in both groups were not evaluated. In the presented study, a statistically significant decrease in both mean systolic and diastolic blood pressures was observed in Group 1, which had had more prophylactic consultations. The year-long cardiovascular disease prophylaxis programme proved less effective than expected - no decrease in body weight (which remained unchanged) nor improvement in lipid metabolism was achieve by either of the groups. A statistically significant increase in BMI and waist circumference was observed in Group 2, compared with Group 1. Body weight is the most difficult to modify of the healthy lifestyle elements. Studies regarding the maintenance of appropriate body weight were also pessimistic [13]. Furthermore, no favorable changes in the lipid profile were observed, and even less favourable changes occurred in Group 2. According to the literature, the effectiveness of consultations on lifestyle changes is low, i.e. 5-10\% [14]. A significant number of worldwide studies on CVD prevention have used a variety of prophylactic measures, and usually several methods were employed simultaneously (medical consultations, phone consults, leaflets, educational materials, online information, etc.). The studies are often conducted by specialized teams which include cardiologists, specialists in, and/or physical activity. Therefore, is difficult to find a common ground to compare the effectiveness, also in terms of economy, of these studies and the prophylactic methods used. The most effective method of CVD prophylaxis has yet to be found. The effectiveness reflected in decreased blood pressure $[13,15]$, reduced body weight, reduced lipid levels, and reduced risk factors, such as smoking status and insufficient physical activity $[16,17$, 18] have been shown in a number of studies and 6-month or 12-month observations involving interventions aimed at changes in lifestyle. It is emphasized that dietary advice and physical activity recommendations are more effective when implemented simultaneously than when used alone [17]. A French study [18] in patients with metabolic syndrome proved the effectiveness of a 6-month intervention which involved promoting lifestyle changes by general practitioners; however, the identification of factors affecting this success was not possible. An English study [16] conducted with the assistance of dietitians and specialists in physical activity, showed increased physical activity, reduced body weight, lower blood pressure and lipid levels in patients who had been provided with more prophylactic consultations [16]. A study on the effectiveness of preventive measures in a general physician's practice was conducted at the Department of Family Medicine in Poznan, Poland [19]. Positive effects were obtained for all analyzed parameters (hypertension, lipid metabolism, body weight) after a year of the study. However, the authors did not specify whether their patients were pharmacologically treated due to hypertension or other conditions, and if the achieved effect was merely the result of prophylactic consultations.

In the presented study, a statistically significant decrease in total cardiovascular risk - according to the SCORE algorithm - was observed in Group 1 (with more prophylactic consultations). This result is similar to a Canadian study which involved primary prophylactic intervention of low intensity (telephone consultations with a nurse) [20]. The decrease in SCORE value in Group 1 was mainly affected by a statistically significant reduction in blood pressure. This may be associated with the fact that Group 1 received more diet consultations than Group 2, and this could have led to reduced blood pressure.

\section{CONCLUSIONS}

1. The prevalence of CVD risk factors in the study population was comparable to the prevalence of these risk factors in the countrywide population.

2. A higher number of preventive consultations had an impact on a statistically significant decrease in mean systolic and diastolic blood pressure, as well as on total cardiovascular risk calculated using the SCORE algorithm.

3. The study failed to achieve decreased body weight and improved lipid metabolism. A statistically significant deterioration in parameters such as BMI, waist circumference, and triglyceride levels, was observed in Group 2, in contrast to Group 1.

4. The implementation of prophylactic interventions based on a general physician's practice requires the development of an effective system to encourage and motivate patients to initiate preventive measures and to continue them.

\section{REFERENCES}

1. Wolniej zmniejsza się umieralność z powodu chorób układu krążenia. Kurier MP: 66/2011 (1177) http://kardiologia.mp.pl/wiadomosci/show. html?id=61953\&l=1177\&u=39473640 (accessed 19.09.2011) (in Polish).

2. Windak A, Godycki-Cwirko M, Podolec P, Kopec G, Pajak A Rynkiewicz A, et al. Konsensus Polskiego Forum Profilaktyki dotyczący badań przesiewowych w profilaktyce chorób układu krążenia. Forum Profilaktyki 2011; 1(17):1-3 (in Polish).

3. Europejskie wytyczne dotyczące prewencji chorób sercowonaczyniowych w praktyce klinicznej - wersja skrócona. Kardiol Pol. 2008; 66; 4 (supl. 1): 4 (in Polish).

4. Kottke TE, Stroebel RJ, Hoffman RS. JNC - Its more than high blood pressure. JAMA. 2003; 19 (289):2573.

5. Poirier P, Giles TD, Bray GA, Hong Y, Stern JS, PI-Sunyer FX, et al. Obesity and cardiovascular disease: pathophysiology, evaluation, and effect of weight loss: an update of the 1997 American Heart Association Scientific Statement on Obesity and Heart Disease from the Obesity Committee of the Council on nutrition. Physical Activity, and Metabolism. Circulation. 2006;113: 898-918. 
6. Podolec P (ed). Podręcznik Polskiego Forum Profilaktyki. Med Prakt. 2007; 1(93): 97-100, 127, 159, 161,169-171, 261-266, 329-332.

7. Puska P. From Framingham to North Karelia. From descriptive epidemiology to public health action. Prog Cardiovasc Dis. 2010; 53: $15-20$.

8. Cipriani V, Mannucci PM, Ardissino D, Ferrario M, Corsini G, Merlini PA, et al. Familial aggregation of early-onset myocardial infarction. Eur J Intern Med. 2010; 21(6): 511-515.

9. Podolec P, Kopeć G. Rozpowszechnienie nadwagi i otyłości w populacji dorosłych Polaków - wyniki badania POLSCREEN. In: Cieśliński A, Pająk A, Podolec P, Rynkiewicz A, (eds). Ogólnopolski Program Prewencji Choroby Wieńcowej POLSCREEN. Termedia, Poznań 2006 (in Polish).

10. Podolec P (ed). Podręcznik Polskiego Forum Profilaktyki. Med Prakt. 2010; 2: 182-185 (in Polish).

11. Biela U, Pająk A, Kaczmarczyk-Chałas K, Głuszek J, Tendera M, Waśkiewicz A, et al. Incidence of overweight and obesity in women and men between the ages of 20-74. Results of the WOBASZ program. Kardiol Pol. 2005; 63:6 (Supl.4): S1-S4.

12. Jóźwiak J, Lukas W, Mastej M, Windak A, Tomasik T, Rygiel K, et al. Ocena częstości występowania klasycznych czynników ryzyka sercowonaczyniowego oraz chorób kardiologicznych i cukrzycy w obserwacji pacjentów badania LIPIDOGRAM 5 lat. Porównanie wyników badań LIPIDOGRAM2004 i LIPIDOGRAM2006. Probl Med Rodz. 2010; XII (Supl.1): 21 (in Polish).

13. Szyndler A. Wpływ edukacji pacjentów z nadciśnieniem tętniczym na kontrolę ciśnienia tętniczego. Rozprawa doktorska. Katedra
Nadciśnienia Tętniczego i Diabetologii Akademii Medycznej w Gdańsku. 2005.

14. Kottke TE. Battista RN, DeFriese GH, Brekke ML. Attributes of successful smoking cessation interventions in medical practice. A meta-analysis of 39 controlled trials. JAMA. 1988; 259: 2883 -2889.

15. Lien LF, Brown AJ, Ard JD, Loria C, Erlinger TP, Feldstein AC, et al. Effects of PREMIER Lifestyle Modifications on participants with and without the metabolic syndrome. Hypertension. 2007; 50: 609-616.

16. Hardcastle S, Taylor A, Bailey M, Castle R. A randomized controlled trial on the effectiveness of a primary health care based counseling intervention on physical activity, diet and CHD risk factors. Patient Educ Couns. 2007; 70: 31-39.

17. Anderson SA, Carroll S, Urdal P, Holme I. Combined diet and exercise intervention reverses the metabolic syndrome in middle-aged males: results from the Oslo Diet and Exercise Study. Scand J Med Sci Sports. 2007; 17; 687-695.

18. Bihan H. Takbou K, Cohen R, Michault A, Boitou F, Reach G, Le Clésiau $\mathrm{H}$. Impact of short-duration lifestyle intervention in collaboration with general practitioners in patients with the metabolic syndrome. Diab Metab. 2009; 35:185-191.

19. Pachciarek G, Celczyńska-Bajew L, Horst-Sikorska W. Skuteczność działań profilaktycznych dotyczących wybranych czynników ryzyka chorób układu sercowo -naczyniowego podejmowanych w praktyce lekarza rodzinnego u chorych na nadciśnienie tętnicze. Fam Med Prim Care Rev. 2008; 10 (3): 591-593.

20. Wister A, Loewen N, Kennedy-Symonds H, McGowan B, McCoy B, Singer J. One-year follow-up of a therapeutic lifestyle intervention targeting cardiovascular disease risk. CMAJ. 2007; 177(8): 859-65. 